\title{
African dust outbreaks over the western Mediterranean Basin: 11-year characterization of atmospheric circulation patterns and dust source areas
}

\author{
P. Salvador ${ }^{1}$, S. Alonso-Pérez ${ }^{2,3,4}$, J. Pey ${ }^{2,5}$, B. Artíñano ${ }^{1}$, J. J. de Bustos ${ }^{3}$, A. Alastuey ${ }^{2}$, and X. Querol ${ }^{2}$ \\ ${ }^{1}$ Environmental Department of the Research Center for Energy, Environment and Technology (CIEMAT) - Unidad Asociada \\ en Contaminación Atmosférica CSIC-CIEMAT, Avenida Complutense 40, 28040 Madrid, Spain \\ ${ }^{2}$ Institute of Environmental Assessment \& Water Research (IDÆA-CSIC). c/Jordi Girona 18, 08034 Barcelona, Spain \\ ${ }^{3}$ Centro de Investigación Atmosférica de Izaña, Agencia Estatal de Meteorología (AEMET) c/La Marina 20, Santa Cruz de \\ Tenerife, 38071, Spain \\ ${ }^{4}$ Universidad Europea de Canarias, Laureate International Universities, C/Inocencio García, 1, 38300 La Orotava, Spain \\ ${ }^{5}$ Aix-Marseille Université, CNRS, LCE FRE 3416, Marseille, 13331, France
}

Correspondence to: P. Salvador (pedro.salvador@ciemat.es)

Received: 13 January 2014 - Published in Atmos. Chem. Phys. Discuss.: 3 March 2014

Revised: 27 May 2014 - Accepted: 29 May 2014 - Published: 3 July 2014

\begin{abstract}
The occurrence of African dust outbreaks over different areas of the western Mediterranean Basin were identified on an 11-year period (2001-2011). The main atmospheric circulation patterns causing the transport of African air masses were characterized by means of an objective classification methodology of atmospheric variable fields. Next, the potential source areas of mineral dust, associated to each circulation pattern were identified by trajectory statistical methods. Finally, an impact index was calculated to estimate the incidence of the African dust outbreaks produced during each circulation pattern, in the areas of study.

Four circulation types were obtained (I-IV) and three main potential source areas of African dust were identified (Western Sahara and Morocco; Algeria; northeastern Algeria and Tunisia). The circulation pattern I ( $24 \%$ of the total number of episodic days) produced the transport of dust mainly in summer from Western Sahara, southern Morocco and Tunisia. The circulation pattern IV (33\%) brings dust mainly from areas of northern and southern Algeria in summer and autumn, respectively. The circulation pattern II (31\%) favored the transport of dust predominantly from northern Algeria, both in spring and summer. Finally, the circulation type III was the less frequently observed (12\%). It occurred mainly in spring and with less intensity in winter, carrying dust from Western Sahara and southern Morocco.
\end{abstract}

Our findings point out that the most intense episodes over the western Mediterranean Basin were produced in the summer period by the circulation type I (over the western side of the Iberian Peninsula) and the circulation type IV (over the central and eastern sides of the Iberian Peninsula and the Balearic Islands).

\section{Introduction}

Mineral dust is the second largest source of natural aerosols. North African deserts emit most of the dust particles released to the atmosphere worldwide. In this context, a persistent outflow of Saharan dust is transported westwards, towards the Caribbean, the eastern coasts of North America and South America (Prospero et al., 1981; Prospero, 1999; Prospero and Lamb, 2003). Large quantities of mineral dust are also carried across the Mediterranean Basin to Europe and the Middle East (Moulin et al., 1998) in episodic intervals and/or following seasonal patterns (Querol et al., 2009; Pey et al., 2013). During such African dust outbreaks (ADO) mineral dust represents a significant contribution to daily $\mathrm{PM}_{10}$ levels registered at rural and urban monitoring sites in the Mediterranean Basin (Querol et al., 1998; 2004; 2008; 2009; Escudero et al., 2007a; Gerasopoulos et al., 2006; Bouchlaghem 
et al., 2009; Pey et al., 2013). Some recent studies demonstrated that a relevant percentage of the exceedances of the $\mathrm{PM}_{10}$ daily limit value (50 $\mu \mathrm{g} \mathrm{m}^{-3}$ after the 2008/50/EC European Directive) registered at these sites can be exclusively attributed to the African dust contribution transported during ADO (Escudero et al., 2007b; Viana et al., 2010; Salvador et al., 2013).

In light of recent research, acute effects on human health in the western Mediterranean Basin could be attributed to the African dust (Pérez et al., 2008; Tobías et al., 2011a, b). More recently, Reyes et al. (2014) found a significant increase in respiratory-cause hospital admissions associated with $\mathrm{PM}_{10}$ and $\mathrm{PM}_{10-2.5}$ fractions during $\mathrm{ADO}$ in Madrid (Spain). It should be noted that aside from mineral dust, anthropogenic pollutants (Rodríguez et al., 2011) and microorganisms (Palmero et al., 2011) have been transported during these events.

Previous studies have explained the important differences between the seasonal occurrence of ADO and the impact of the African dust on ambient concentrations of particulate matter over the western, central and eastern Mediterranean Basin (Moulin et al., 1998; Querol et al., 2009; Pey et al., 2013). In this study we will focus on the atmospheric processes which originate the transport of African dust towards the western Mediterranean Basin.

With the aim to document the occurrence of ADO over different areas of the western Mediterranean Basin and to characterize their seasonal trends, air mass classifications were frequently carried out by means of backward air trajectories, either by straightforward attribution of their origin (Querol et al., 1998, 2004; Artíñano et al., 2001; Rodríguez et al., 2001) or cluster analysis (Salvador et al., 2008, 2013). Otherwise, different interpretations of the meteorological scenarios causing ADO were performed. Many studies have shown specific days of the study period as examples of the most outstanding synoptic situations favoring the transport of African air masses (Rodríguez et al., 2001; Viana et al., 2003; Querol et al., 2009). Escudero et al. (2005) generated composite maps of sea level pressure and geopotential height at 850 and $700 \mathrm{hPa}$ levels, by averaging the first day of each ADO over eastern Spain during the 1996-2002 period, after a visual classification of events. Salvador et al. (2013) grouped air masses arriving on a daily basis over the center of the Iberian Peninsula, during the 2001-2008 period, into homogeneous groups by means of a cluster analysis of back trajectories. Trajectories coming from North African regions were grouped into a single cluster, and they were used to create seasonally composite $850 \mathrm{hPa}$ geopotential height maps.

The results obtained in these works could be considered as approaches on the characterization of ADO over specific areas of the western Mediterranean Basin from a meteorological perspective. With the aim of yielding a more systematic perspective, this study deals with this region as a whole. All the ADO occurring in this area from 2001 to 2011 were analyzed. Additionally, an estimation of the African dust con- tribution to the $\mathrm{PM}_{10}$ daily mean levels was obtained, during each event for each region of study. Such a long temporal series of $\mathrm{ADO}$ occurrence and African dust estimates in $\mathrm{PM}_{10}$ is hardly found in the literature. Part of this data set, among others, was analyzed by Pey et al. (2013) to characterize the occurrence of ADO across the whole Mediterranean Basin. Issues related to levels of dust concentration, seasonal patterns and frequency of the events across the Mediterranean were discussed and evaluated. In this study the main atmospheric processes which give rise to the ADO are characterized and the source areas of dust are identified using different objective statistical procedures. The seasonality and the geographical differences within the areas of study where ADO occur are described.

Alonso-Perez et al. (2011) also achieved an objective characterization of meteorological scenarios, favoring high African dust concentrations into the marine boundary layer of the subtropical eastern north Atlantic region, with the purpose to complement previous studies describing ADO in the same area (Viana et al., 2002). The phenomenology of these events is different in the subtropical eastern north Atlantic region in comparison with the western Mediterranean Basin, with clear differences in their seasonal trends and the associated meteorological patterns (Viana et al., 2002; Alonso-Perez et al., 2011). However the methodology used by Alonso-Perez et al. (2011), to objectively characterize synoptic meteorological patterns, was also used in the present study.

Firstly, daily patterns of geopotential height at the $850 \mathrm{hPa}$ pressure level corresponding to episodic days were grouped into homogeneous groups, each one representing a characteristic atmospheric circulation type, by nonhierarchical $K$ means cluster analysis and by principal component analysis. Synoptic situations which give rise to these circulation types, were characterized by composite synoptic maps of sea level pressure and geopotential height at the 850 and $700 \mathrm{hPa}$ pressure levels. The seasonal occurrence of ADO during each circulation type was analyzed. Then, the potential source areas of the mineral dust transported during each circulation type were estimated by trajectory statistical methods. Finally an estimation of the impact of the ADO over each one of the regions of study was carried out.

\section{Methodology}

During the 2001-2011 period, the occurrence of ADO over different regions of the western Mediterranean Basin was identified using a robust methodology, which consists in the daily interpretation of meteorological products and air mass back trajectories. This procedure can be found elsewhere (Escudero et al., 2005, 2007b) and consequently will not be described here in detail.

Then, daily data from nine regional background air quality monitoring sites were obtained during this 11 -year period, 

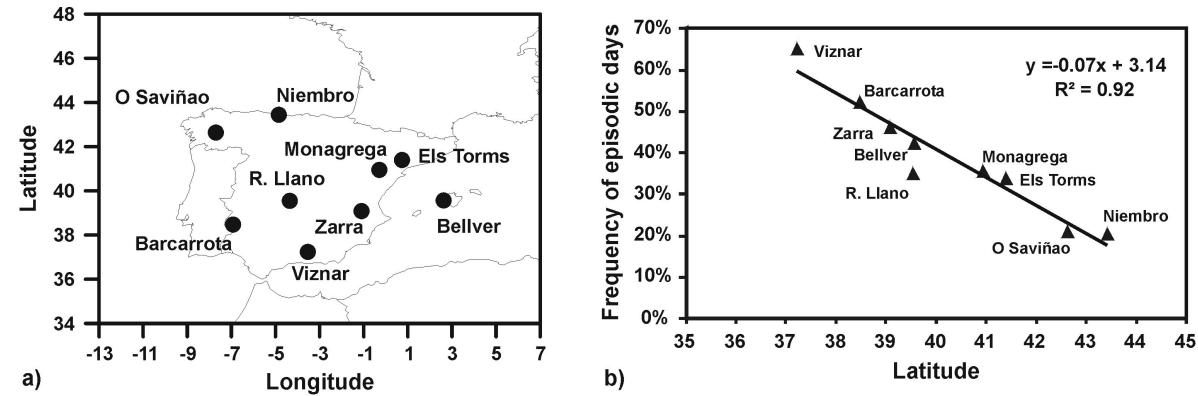

Figure 1. Location of regional background air quality monitoring sites used in this study (a) and relationship between their latitudes and the frequency of episodic days registered at them (b).

to evaluate the African dust contributions and to assess their impact on $\mathrm{PM}_{10}$ levels. Table 1 lists the various stations used in this study. Seven out of the nine stations are members of EMEP (Co-operative Programme for Monitoring and Evaluation of the Long-Range Transmission of Air Pollutants in Europe). Of the remaining sites, Bellver belongs to the Balearic Islands Regional Air Quality Network whereas Monagrega is part of the ENDESA (Empresa Nacional de Electricidad S.A.) Air Quality Network. Two different techniques have been used to determine $\mathrm{PM}_{10}$ concentrations: gravimetric determinations at the EMEP sites and real-time monitors based on beta gauge attenuation at Monagrega and Bellver. In these two monitoring sites the real-time concentrations were corrected against the gravimetric ones. Since only the official data reported to the European Commission are used in this work, their quality is guaranteed.

These monitoring sites were selected according to data coverage and geographical location criteria; they were the regional background sites with the best data coverage of $\mathrm{PM}_{10}$ daily mean values in the period of study $\left(\mathrm{PM}_{10}\right.$ daily data coverage ranging from 84 to $99 \%$ ). Additionally, they were distributed throughout the Iberian Peninsula and the Balearic Islands, covering the southeastern, southwestern, central, eastern, northeastern, northern and northwestern regions (Fig. 1a). It should be noted that until the year 2004, no rural background station was recording $\mathrm{PM}_{10}$ concentration levels on a regular basis in Portugal. For this reason Portugal was not considered in this work.

Then, a specific procedure was applied for the quantification of the African dust contribution deposited during each $\mathrm{ADO}$ at each sampling site, to estimate the impact of the African dust on the $\mathrm{PM}_{10}$ daily records. Studies made on the levels of $\mathrm{PM}_{10}$ registered at EMEP and other regional background stations in the Iberian Península (Escudero et al., 2007b; Viana et al., 2010) showed that the 30-day moving 40th percentile determined for each day, excluding the African dust episodic days, reproduces rather suitably the regional background levels of the study area during periods with prevailing atmospheric advective conditions. Thus, at regional background monitoring sites, the origin of the
$\mathrm{PM}_{10}$ levels recorded during these days must be local or regional. Consequently this methodology is built on the identification of days with African dust transport and statistical analyses based on the calculation of the 30-day moving 40th percentile for regional background $\mathrm{PM}_{10}$ daily concentration time series. This percentile is an indicator of the non-African regional background to be subtracted from the daily $\mathrm{PM}_{10}$ levels during ADO, and thus allows calculating the daily African dust contribution.

The feasibility of this method was demonstrated by different approaches in Escudero et al. (2007b) and Viana et al. (2010). This methodology became the Spanish and Portuguese reference method to identify and quantify African dust contributions to $\mathrm{PM}_{10}$ levels since 2004. The method is also applicable across all of southern Europe, as demonstrated by Querol et al. (2009) and more recently by Pey et al. (2013). Currently, this is one of the official methods recommended by the European Commission for evaluating the occurrence of ADO and quantifying its contributions (Commission staff working paper, 2011).

As a consequence of this preliminary analysis, days with a positive value of African dust contribution in at least one of the nine regional background monitoring sites during the 2001-2011 period were identified. Henceforth they will be referred to as "episodic days". This study will focus on such episodic days and on the values of the African dust contributions estimated at each sampling site.

\subsection{Circulation classifications methodology}

First of all, gridded sea level pressure and geopotential height fields at 850 and $700 \mathrm{hPa}$ in the geographical domain, defined as $0-60^{\circ} \mathrm{N}, 30^{\circ} \mathrm{W}-30^{\circ} \mathrm{E}$, were extracted from the ERA-Interim Archive at ECMWF (European Centre for Medium-Range Weather Forecasts) for the period 20012011. The ERA-Interim atmospheric model and reanalysis system uses the cycle 31r2 version of the ECMWF's Integrated Forecast System, which was configured for the following spatial resolution: 60 levels in the vertical, with the top level at $0.1 \mathrm{hPa}$; T255 spherical-harmonic representation for the basic dynamical fields; a reduced Gaussian grid with 
Table 1. Location, $\mathrm{PM}_{10}$ daily data availability during the 2001-2011 period and measurement methods used in the air quality monitoring sites of this study (EMEP stations in bold).

\begin{tabular}{llllrcl}
\hline Site & Location & Latitude & Longitude & m a.s.l. & $\%$ Data & Method \\
\hline O Saviñao & NW IP & $42^{\circ} 38^{\prime} 05^{\prime \prime} \mathrm{N}$ & $07^{\circ} 42^{\prime} 17^{\prime \prime} \mathrm{W}$ & 506 & $90 \%$ & GRAV \\
Barcarrota & SW IP & $38^{\circ} 28^{\prime} 22^{\prime \prime} \mathrm{N}$ & $06^{\circ} 55^{\prime} 25^{\prime \prime} \mathrm{W}$ & 393 & $90 \%$ & GRAV \\
Viznar & SE IP & $37^{\circ} 14^{\prime} 14^{\prime \prime} \mathrm{N}$ & $03^{\circ} 32^{\prime} 03^{\prime \prime} \mathrm{W}$ & 1230 & $93 \%$ & GRAV \\
Niembro & N IP & $43^{\circ} 26^{\prime} 21^{\prime \prime} \mathrm{N}$ & $04^{\circ} 51^{\prime} 00^{\prime \prime} \mathrm{W}$ & 134 & $87 \%$ & GRAV \\
Risco Llano & Central IP & $39^{\circ} 32^{\prime} 49^{\prime \prime} \mathrm{N}$ & $04^{\circ} 21^{\prime} 02^{\prime \prime} \mathrm{W}$ & 917 & $86 \%$ & GRAV \\
Zarra & E IP & $39^{\circ} 04^{\prime} 58^{\prime \prime} \mathrm{N}$ & $01^{\circ} 06^{\prime} 04^{\prime \prime} \mathrm{W}$ & 885 & $94 \%$ & GRAV \\
Els Torms & NE IP & $41^{\circ} 23^{\prime} 38^{\prime \prime} \mathrm{N}$ & $00^{\circ} 44^{\prime} 05^{\prime \prime} \mathrm{E}$ & 470 & $91 \%$ & GRAV \\
Monagrega & NE IP & $40^{\circ} 56^{\prime} 48^{\prime \prime} \mathrm{N}$ & $00^{\circ} 17^{\prime} 27^{\prime \prime} \mathrm{W}$ & 570 & $99 \%$ & BETA \\
Bellver & Balearic Islands & $39^{\circ} 33^{\prime} 50^{\prime \prime} \mathrm{N}$ & $02^{\circ} 37^{\prime} 22^{\prime \prime} \mathrm{E}$ & 117 & $84 \%$ & BETA \\
\hline
\end{tabular}

IP: Iberian Peninsula; GRAV: gravimetric; BETA: beta attenuation monitor; a.s.l.: above sea level.

approximately uniform $79 \mathrm{~km}$ spacing for surface and other grid-point fields. Additional information is contained in Dee et al. (2011).

Next, a nonhierarchical $K$-means cluster analysis method was applied for classifying time series of daily fields of geopotential height at the $850 \mathrm{hPa}$ pressure level, into similar groups or "circulation types" (Huth et al., 2008). This method is based on the minimization of the sum of quadratic Euclidean distances between the data points of the $n$ observations of a variable, and the corresponding centroid of each cluster. In this particular case, this algorithm is used to globally diminish the intragroup distance, classifying the geopotential height fields into $K$ groups (Alonso-Pérez et al., 2011). The number of clusters to be retained must be chosen a priori; it was determined by computing the percentage change in the within-cluster variance, as a function of the number of the clusters (Dorling et al., 1992). This statistic increases abruptly when clusters which are significantly different are joined, helping to choose the best number of clusters to be retained.

The nonhierarchical $K$-means cluster analysis method was selected on the basis of a number of the main criteria. First of all, it is considered that nonhierarchical $K$-means method outperforms hierarchical cluster analysis in general (Gong and Richman, 1995; Michelangeli et al., 1995; Philipp et al., 2007). Additionally, Huth (1996) and Huth et al. (2008) demonstrated that in comparison with other classification methodologies, $K$-means provides excellent separability among cluster, good temporal and spatial stability and a moderate ability to reproduce known underlying structure of data. Huth (1996) also stated that if the preferred property is the separation (among clusters as well as between clusters and the whole data set), the $K$-means method is best.

It should be noted that principal component analysis (PCA) has also been widely used for circulation pattern classification. Several studies can be found in the literature, concluding that rotated principal components are the most accurate method for circulation pattern classification, if the goal of the study was centered on the ability to reproduce known patterns (Gong and Richman, 1995; Huth, 1996). However these authors also demonstrated that there is not a classification method which is best in all aspects among other tested. In the end, each of the methods removes the subjectivity inherent in classification procedures to a certain extent, although leaving some decisions on the classification subject.

Alonso-Pérez et al. (2011) demonstrated that $K$-means and PCA can be complementary and related methods in circulation classifications. For this reason and with the aim to validate the circulation types obtained with the $K$-means procedure, a PCA in T mode (grid point values in rows and cases in columns) was carried out with the same data set of $850 \mathrm{hPa}$ daily fields. The same number of principal components and clusters was obtained. Finally the resulting circulation types, obtained by averaging the $850 \mathrm{hPa}$ geopotential height daily fields corresponding to those days assigned to each cluster and principal component, were compared and their "physical meaning" was analyzed. When we talk about "physical meaning" we are referring to circulation patterns which were detected during all the years of the period of study, with a common seasonal trend and geographical area of influence.

More specific details on the use of $K$-means cluster analysis and PCA as classification methods can be found in Alonso-Perez et al. (2011).

Finally, it should be noted that, unlike weather-type classification, circulation pattern classification is based on just one parameter of atmospheric circulation (Yarnal, 1993). Studies using multiple levels (Kidson, 1997; Romero et al., 1999) indicate that owing to a high degree of dependence among individual layers, the inclusion of additional levels yields only little extra information over using a single level. AlonsoPérez et al. (2011) did not find significant variations in the total variance fraction explained by each PC (principal component) and the percentage of the African intrusion days occurred under synoptic meteorological patterns explained by each $K$-means cluster at different levels $(1000,850,700$ and $500 \mathrm{hPa}$ ). In the present work, daily fields of geopotential 
height at the $850 \mathrm{hPa}$ pressure level were selected, because in most of the cases they correctly describe the mean transport wind at a synoptic scale during ADO towards the western Mediterranean Basin (Moulin et al., 1998; Querol et al., 1998; Salvador et al., 2004). In fact, previous studies stated that the transport of African dust towards this area mostly occurs at relatively high atmospheric levels (Escudero et al., 2005; Querol et al., 2009; Pey et al., 2013). The Atlas Mountains range, extending from Western Sahara towards Tunisia, hinders the transport of dust at low altitudes from occurring.

\subsection{Identification of potential source areas of dust}

It is recognized that the statistical analysis of a great number of back trajectories from receptor sites, has turned out to be a valuable tool to identify sources and sinks of atmospheric trace substances or to reconstruct their average spatial distribution (Stohl, 1998; Scheifinger and Kaiser, 2007). In this study, the redistributed concentration field (RCF) method (Stohl, 1996) was used to identify potential source areas of the mineral dust transported during ADO towards the western Mediterranean Basin.

Five day backward 3-D air trajectories arriving at all of the nine sampling sites at 00:00, 06:00, 12:00 and 18:00 UTC (Coordinated Universal Time) were computed for each day of the 2001-2011 period, using the HYSPLIT (Hybrid Single-Particle Lagrangian Integrated Trajectory) model (Draxler and Rolph, 2003). The fixed height of $1500 \mathrm{~m}$ a.s.1. was chosen as the air masses' arrival height, because this altitude approximately coincides with the $850 \mathrm{hPa}$ geopotential height pressure level. In all, more than 22000 trajectories corresponding to episodic days were available for analysis, each with 120 endpoints.

RCFs were computed over the region defined as $12-60^{\circ} \mathrm{N}$, $28^{\circ} \mathrm{W}-24^{\circ} \mathrm{E}$. For each $2^{\circ}$ longitude $\times 2^{\circ}$ latitude grid cell, a weighted concentration of African dust was computed using the procedure defined by Stohl (1996). Thus, cells with weighted concentrations in the higher and lower value ranges indicated that, on average, air parcels residing over these cells resulted in high and low concentrations, respectively, of the African dust contributions at the receptor sites. RCF results were reported on geographical maps as a result of the interpolation of the weighted concentrations in the grid cells. These maps show those potential source areas whose emissions can be transported to the measurement site by prevailing synoptic winds (Vinogradova, 2000).

To provide detailed information on the source areas of dust contributing to the different regions of the western Mediterranean Basin, RCF maps were obtained using African dust contribution values and back trajectories from western (Barcarrota and O Saviñao), central (Viznar, Risco Llano and Niembro) and eastern (Zarra, Bellver, Monagrega and Els Torms) regions of the western Mediterranean Basin during each season (spring, summer, autumn and winter) and each circulation type. Lupu and Maenhaut (2002) demonstrated that calculating RCFs with data from several locations improved their spatial resolution.

\subsection{Estimation of the impact index}

With the aim to evaluate the impact of the ADO produced by each circulation type on the concentrations of African dust in $\mathrm{PM}_{10}$ registered at the regional background stations, an impact index was defined. This parameter combined the frequency of occurrence of each circulation pattern with the average African dust levels recorded during each of them at any sampling site. The higher the index, the higher the African dust contributions and the frequency of episodic days.

For each sampling site

$\mathrm{IND}_{i}=\left(\mathrm{ADC}_{i} \cdot N_{i}\right) /\left(\mathrm{ADC} \cdot N_{t}\right) \cdot 100$,

where $\mathrm{IND}_{i}$ is the impact index associated to the circulation pattern $i, \mathrm{ADC}_{i}$ is the average value of African dust contributions registered at this site only for days in which the circulation pattern $i$ occurs, $N_{i}$ is the number of episodic days produced by the circulation pattern $i$ and ADC is the average value of African dust contribution for all the $N_{t}$ episodic days produced in this site. Hence, for each sampling site

$\sum_{i=1}^{4} \mathrm{IND}_{i}=100 \%$

\section{Results and discussion}

\subsection{Circulation classifications}

During the period 2001-2011, 1592 episodic days were identified (on average 145 episodic days per year) increasing the daily concentration levels of $\mathrm{PM}_{10}$ recorded in regional background air quality monitoring stations, due to African mineral dust. The highest number of episodic days was recorded in 2007 (187 days) and the lowest in 2005 (125 days).

The episodic days occurred less frequently at northern locations (21\% at O Saviñao and Niembro) than at central (30-50\% at Els Torms, Monagrega, Risco Llano, Bellver and Zarra) and southern locations (> 50\% at Barcarrota and Viznar) of the area of study (Fig. 1b). At the most southern locations a higher frequency of episodic days was evident due to their higher proximity to the African mainland.

Of the episodic days, $26 \%$ were detected only at one of the sampling sites. Some of these episodic days corresponded to ADO with short duration, which only transported dust to one of the regions. Otherwise, during ADO with duration of several days, mineral dust could be transported to further areas, being firstly detected at borderline sites such as Barcarrota (18\% of the episodic days detected only in this site), Viznar $(22 \%)$ and Bellver $(46 \%)$. Otherwise, $3 \%$ of the episodic days (41 days) were registered simultaneously in all of the stations, during the most intense ADO. 


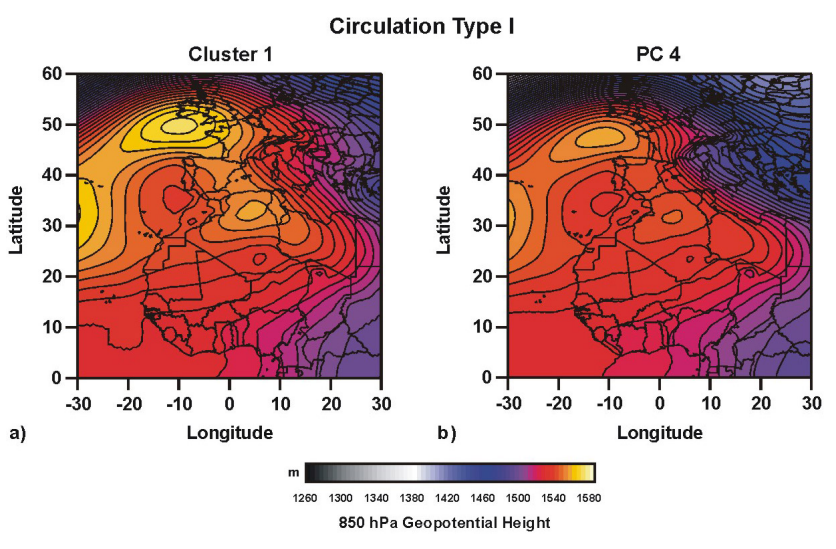

Figure 2. Composite $850 \mathrm{hPa}$ geopotential height (m) representing circulation type I leading to ADO over the western Mediterranean Basin.

On average, the highest number of episodic days was recorded in summer (June-August) followed by those registered in the spring (March-May) and the autumn (September-November) months. The lowest number of episodic days was recorded from December to February (Table 2).

The application of the methodology exposed in Sect. 2.1, to find an appropriate number of clusters in a given dataset, showed a large increase in the percentage change in the within-cluster variance when reducing the number of clusters from seven to six and from four to three. A percentage change of 9.9 and 13.0 was respectively produced. This suggested that seven or four clusters could be retained as the best number for describing significantly different atmospheric circulation patterns in this study. Seven clusters were considered too many, as some of them were composed only by a few episodic days. Moreover, some of these circulation types were not produced during all the years of the study period. In order to have a manageable number of clusters with physical meaning, four clusters were retained for use in this analysis.

Figures 2-5 shows the four composite synoptic maps of the geopotential height at the $850 \mathrm{hPa}$ level, calculated by averaging the data corresponding to all episodic days assigned to a particular cluster after the last iteration in the clustering procedure and principal component (right column). Different orthogonal (varimax) and oblique rotations (oblimin) were checked in the PCA procedure, resulting in equivalent structures. Oblimin-rotated solutions (Huth, 1996) were utilized to create Figs. 2-5. Composite synoptic maps calculated by averaging the sea level pressure and the geopotential height at the $700 \mathrm{hPa}$ level, using the data corresponding to all episodic days assigned to a particular cluster, are depicted in Figs. S1 and S2 in the Supplement.

The main features characterizing the four circulation types that were obtained by $K$-means cluster analysis could be found in the four circulation types obtained from PCA. Circulation patterns resulting from clusters $1-4$ resembled quite

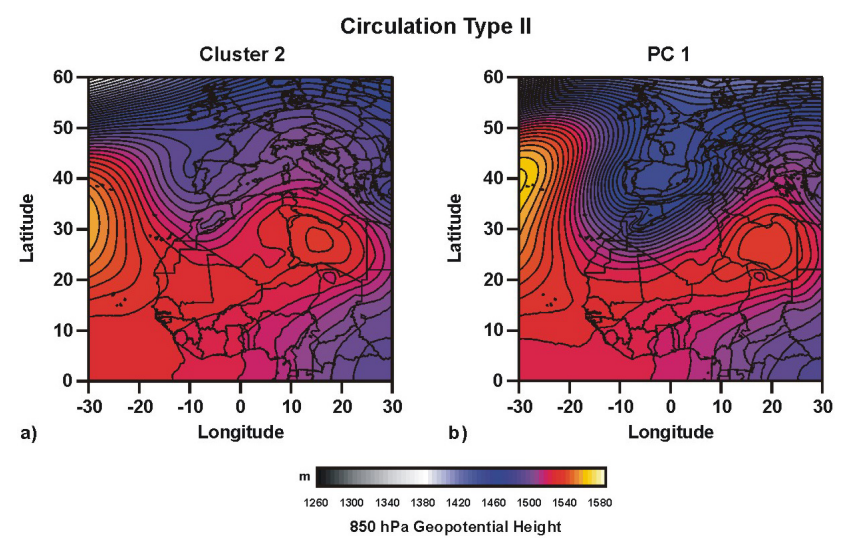

Figure 3. Composite $850 \mathrm{hPa}$ geopotential height (m) representing circulation type II leading to ADO over the western Mediterranean Basin.

well those obtained from PC4, PC1, PC3 and PC2, respectively (Figs. 2-5).

Circulation type I illustrated a synoptic meteorological scenario, characterized by a relative low pressure system observed at the 850 and $700 \mathrm{hPa}$ levels west or southwest of the Iberian Peninsula coast and by an upper level high, located over northern Algeria (Fig. 2). The so-called North African high is a common synoptic feature in all the circulation types giving rise to ADO over the western Mediterranean Basin. It is produced by the intense heating of the North African surface which generates the development of thermal lows. As a consequence, a compensatory high pressure system is formed at higher altitudes over different geographical locations, depending on the circulation pattern. This circulation type favored the advection of African air masses towards the Iberian Peninsula by southern and southwestern winds in the upper atmospheric levels.

Circulation type II was characterized by a shift of the North African high to the east and a trough placed over the western Iberian Peninsula coast (Fig. 3a) or at a somewhat more eastern location on the Iberian Peninsula (Fig. 3b). A small low pressure system, centered over Morocco, was also noticeable. This synoptic meteorological situation generated southwestern winds over the Iberian Peninsula. The composite $700 \mathrm{hPa}$ geopotential height field illustrated a clear southwesterly wind flow with a strong high in southern Algeria, carrying warm air onto the western Mediterranean Basin (Fig. S2b in the Supplement).

It should be noted that other authors identified meteorological scenarios dominated by Atlantic depressions between January and June, inducing transport of African dust towards southern and eastern Spain (Rodríguez et al., 2001; Escudero et al., 2005). Circulation types I and II gathered these scenarios, discriminating between those in which the North African high was located over northeastern Algeria and Tunisia (type I) or at more eastern locations (type II). 
Table 2. Comparison of the four circulation types obtained from Cluster Analysis and Principal Component Analysis.

\begin{tabular}{cccl|ccl}
\hline & \multicolumn{3}{c|}{ Cluster analysis $K$-means } & \multicolumn{2}{c}{ Principal component analysis } \\
\hline Circulation Type & Cluster & $\%$ days & Seasonal trend & PC & $\%$ days & Seasonal trend \\
\hline I & 1 & $24 \%$ & Summer & 4 & $22 \%$ & Summer \\
II & 2 & $31 \%$ & Spring & 1 & $35 \%$ & Spring \\
III & 3 & $12 \%$ & Spring & 3 & $9 \%$ & Spring \\
IV & 4 & $33 \%$ & Summer & 2 & $35 \%$ & Summer \\
\hline
\end{tabular}

$\%$ days: number of episodic days assigned to each cluster or principal component

Seasonal trend: season with the higher frequency of occurrence of the circulation type during the 2001-2011 period.

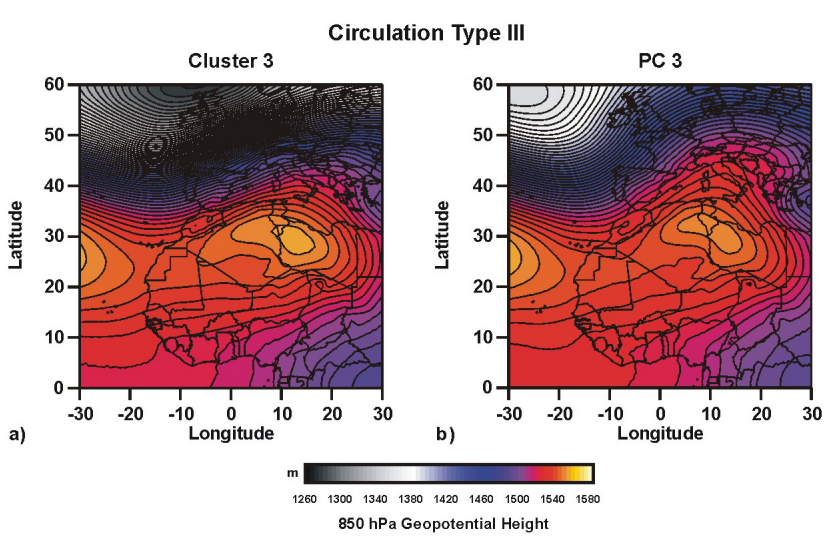

Figure 4. Composite $850 \mathrm{hPa}$ geopotential height $(\mathrm{m})$ representing circulation type III leading to ADO over the western Mediterranean Basin.

Circulation type III showed a strong high pressure system extended over eastern Algeria and Libya in the map of geopotential height at the $850 \mathrm{hPa}$ level. Additionally, a strong longitudinal baric gradient produced by a strong Icelandic low and weak Azores high, which is displaced towards the southwest, caused a clear zonal circulation over the Iberian Peninsula (Fig. 4). This circulation type was not associated in previous studies with dust transport over the western Mediterranean Basin.

The most remarkable feature of the synoptic situation described by the circulation type IV was the development of an intense North African high over northeastern Algeria and Tunisia, advecting warm African air masses onto the Iberian Peninsula from southern and southeastern areas (Fig. 5). At $700 \mathrm{hPa}$, the North African high extended over Western Sahara, Mali and Mauritania, inducing the transport of air masses from these areas towards the Iberian Peninsula and the western Mediterranean Basin. At sea level, an extension of the Azores high over central Europe and a weak pressure gradient, inhibited the transport of air masses at low altitudes. This was the most frequent synoptic meteorological situation causing ADO over eastern (Rodríguez et al., 2001; Escudero et al., 2005) and central (Salvador et al., 2013) Spain.

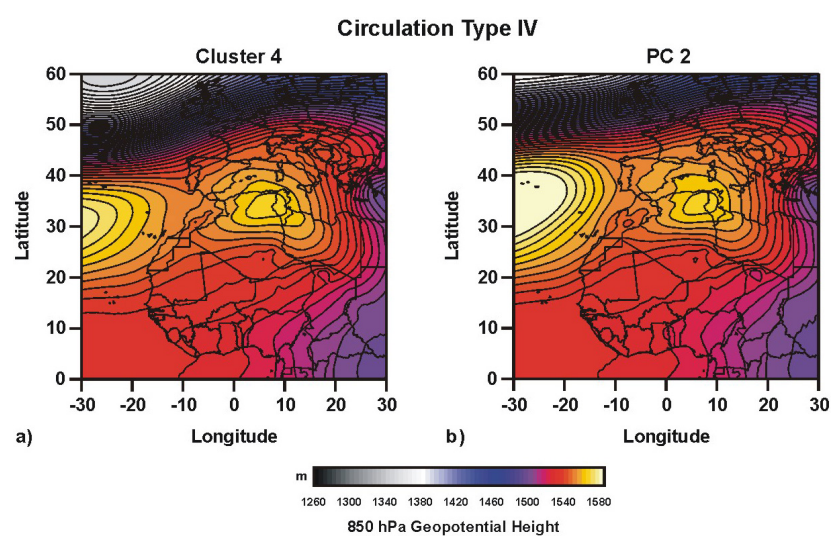

Figure 5. Composite $850 \mathrm{hPa}$ geopotential height $(\mathrm{m})$ representing circulation type IV leading to ADO over the western Mediterranean Basin.

Table 2 shows a comparison of the main features of the 4 circulation patterns obtained with cluster analysis and PCA. It can be concluded that both methodologies produced basically the same results in terms of the frequency of episodic days attributed to each circulation pattern and the prevalent season of the year with a higher frequency of occurrence of episodic days.

For the sake of simplicity, from now on the discussion will be referred to the results obtained exclusively from cluster analysis.

The most frequent patterns were the fourth and the second circulation types, representing 33 and $31 \%$ of the episodic days, respectively. The first circulation type accounted for $24 \%$ of the episodic days whereas the third one grouped the transport regimes less frequently observed. It represented only $12 \%$ of the episodic days (Table 2). Figure 6 shows the monthly distribution of occurrence of the circulation types during the period of study. The number and seasonal frequency of episodic days during each year of the period 20012011 by circulation type can be consulted in Tables S1 and S2 in the Supplement, respectively.

Trend estimates of the occurrence of ADO were undertaken, using the OpenAir data analysis tools (Carslaw and Ropkins, 2012). The magnitude of the trend was expressed 


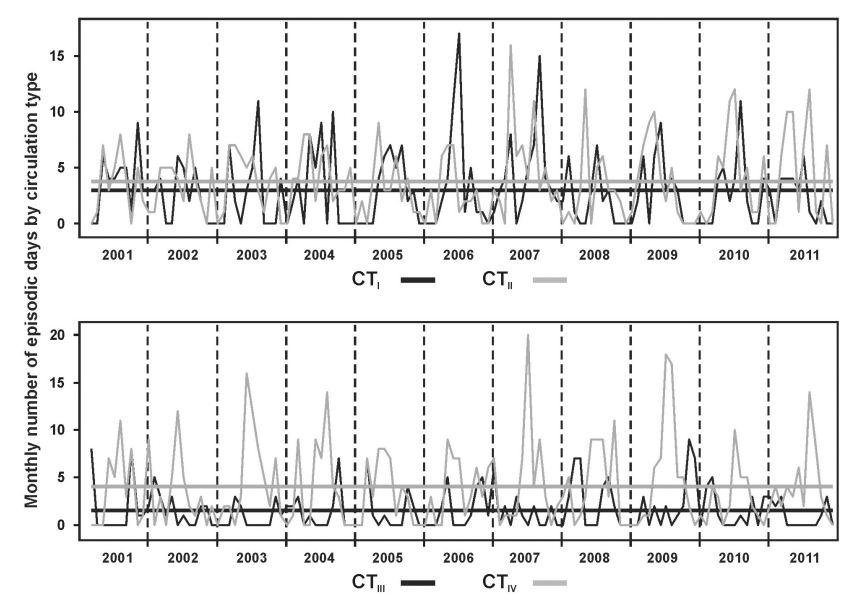

Figure 6. Evolution and smooth trend line in monthly number of episodic days by circulation type (upper: $\mathrm{CT}_{\mathrm{I}}$ and $\mathrm{CT}_{\mathrm{II}}$; bottom: $\mathrm{CT}_{\mathrm{III}}$ and $\left.\mathrm{CT}_{\mathrm{IV}}\right)$ registered over the western Mediterranean Basin from 2001 to 2011.

as a slope using the Theil-Sen method (Hirsch et al., 1982). Smooth trends in the monthly mean concentrations of pollutants were also determined using generalized additive modeling (Carslaw et al., 2007) and represented in Fig. 6. The monthly number of episodic days produced during the different circulation types did not show a significant trend (neither upward nor downward). These results indicate that the occurrence of ADO over the Iberian Peninsula and the Balearic Islands, under the four prevalent circulation types obtained, maintained a steady tendency during the period 2001-2011. This fact is evidenced in Fig. 3 by the horizontal lines, representing the smooth trends.

Table 3 and Fig. 6 illustrate that a marked seasonal pattern is observed in the occurrence of the different circulation types. There was a clear seasonal trend towards a higher frequency of the circulation type I episodic days during the summer months and in lesser extent during spring and autumn. The episodic days that occurred during the circulation type II were more frequent during the spring and the summer months. The meteorological scenarios represented by the circulation type III occurred predominantly in spring and autumn and less frequently during summer. In opposition, episodic days generated by the circulation type IV were more likely registered in summer.

Moulin et al. (1997) found that interannual variations in dust transport from North Africa towards the Atlantic Ocean and the Mediterranean Sea were well correlated with the climatic variability defined by the North Atlantic Oscillation (NAO) index. This index was defined by Hurrell (1995), and accounts for the difference between the normalized sea-level atmospheric pressures between Lisbon, Portugal, and Stykkisholmur, Iceland. It has the limitation that these stations are fixed in space and thus may not track the movement of the NAO centers of action through the annual cycle. Besides, in- dividual station pressure readings can be noisy due to smallscale and transient meteorological phenomena unrelated to the NAO.

When this pressure gradient between the Icelandic low and the subtropical high is more intense than normal (positive NAO) the westerly winds are stronger across northern $\mathrm{Eu}-$ rope, bringing Atlantic air masses over the continent associated with mild temperatures and higher precipitation. In contrast, dryer conditions than usual are produced at lower latitudes across southern Europe. When the pressure gradient is less intense than normal (negative NAO) the track of westerly Atlantic winds is observed at lower latitudes, bringing stronger than normal winds over the Mediterranean. Moreover, in recent published works, winter (Cusack et al., 2012) and summer (Pey et al., 2013) periods with positive and negative NAO index values were associated with more and less frequent ADO, respectively, over areas of the Iberian Peninsula and the northwestern region of the Mediterranean Basin.

Pey et al. (2013) detected a modification in the atmospheric circulations for the summer periods of the 20072008 biennium. It was associated to a change in the NAO index, towards more negative values than usual. As a consequence, an unusual displacement of warm air masses transporting African dust towards the central Mediterranean was detected during these summer periods, although still affecting northeastern Spain and the Balearic Islands. The highest frequency of episodic days produced by the circulation type III in summer was detected in 2007 (19\% of the annual number of episodic days associated to this circulation type) and $2008(15 \%)$. During the other years of the period of study this frequency ranged from 0 to $8 \%$, demonstrating that the occurrence of the circulation type III in the summer period can only be achieved under atypical atmospheric conditions (Table S2 in the Supplement).

In this work, the annual and monthly mean NAO indexes for the 2001-2011 period were obtained from the NOAA data center (http://www.cpc.ncep.noaa.gov/products/precip/ CWlink/pna/nao.shtml) and compared with the occurrence of episodic days according to the four circulation types. They did not always show a statistically significant linear correlation across all the seasons and the years of the period 20012011. This fact evidences that other factors related to largescale dynamical features, apart from the NAO index, contribute to the year-to-year variability of the occurrence of ADO and the intensity of dust export (Moulin et al., 1997).

Anyway, a remarkable result was found in relation with the development of different circulation types during periods with a high or low NAO index. Figure 7a depicts the good fitting between the annual occurrence of the circulation types II and III episodic days and the corresponding annual NAO index values. This behavior was especially intense during spring (Fig. 7b). In this period, circulation types I and II showed a positive linear relationship with the value of the NAO index. The opposite was found with the circulation type III. It should be noted that the year 2010 was excluded 
Table 3. Occurrence of episodic days during the period 2001-2011 and during each circulation type $\left(\mathrm{CT}_{i}\right)$.

\begin{tabular}{lrrrrr}
\hline & $2001-2011$ & $\mathrm{CT}_{\mathrm{I}}$ & $\mathrm{CT}_{\mathrm{II}}$ & $\mathrm{CT}_{\mathrm{III}}$ & $\mathrm{CT}_{\mathrm{IV}}$ \\
\hline$N$ & 1592 & 387 & 489 & 196 & 520 \\
Winter & $11 \%$ & $11 \%$ & $10 \%$ & $22 \%$ & $9 \%$ \\
Spring & $27 \%$ & $22 \%$ & $39 \%$ & $37 \%$ & $15 \%$ \\
Summer & $40 \%$ & $45 \%$ & $35 \%$ & $6 \%$ & $53 \%$ \\
Autumn & $22 \%$ & $21 \%$ & $16 \%$ & $35 \%$ & $22 \%$ \\
\hline
\end{tabular}

$N$ : number of episodic days.

from the correlation plot (Fig. 7a) owing to the atypical low values of the NAO index obtained across all the seasons (annual NAO index $=-1.65$ ). It is evident that this year was governed by anomalous atmospheric patterns.

This fact suggests that during specific low-NAO periods, the transport of African dust towards the western Mediterranean Basin could be achieved, in spite of the fact that zonal flows prevailed over this area. This situation was depicted in Fig. 8a, which represents the mean geopotential height at $850 \mathrm{hPa}$ during episodic days in spring 2005 . This was the year with the lower NAO index value in spring. The advection of Atlantic air masses was produced at lower latitudes than usual (grey arrow) but the presence of the high pressure system extended over eastern Algeria, Tunisia and Libya, allowed transporting the African air masses (white arrow) towards the eastern side of the Iberian Peninsula and the Balearic Islands. The similarity between Figs. 8a and 4, illustrates the prevalence of the circulation type III in this period.

On the contrary, periods with higher than normal NAO index values, revealed a different synoptic meteorological situation. During spring 2011 (Fig. 8b) the advection of Atlantic air masses took place at latitudes higher than $45^{\circ} \mathrm{N}$, whereas the low pressure system located over $35^{\circ} \mathrm{N}, 15^{\circ} \mathrm{W}$ and the high pressure system extended again over eastern Algeria, Tunisia and Libya, favored African air masses moving northward. In this period 50 episodic days were identified, most of them caused by the circulation types I (24\%) and II (52\%).

\subsection{Identification of potential source areas of dust}

Prospero et al. (2002) have shown that dust sources are usually associated with topographical lows in arid regions where runoff and flooding have created lacustrine and alluvial sediments. These sediments are composed of fine particles which are easily eroded by winds. Ginoux et al. (2001) determined the global distribution of dust sources taking into account this so-called "topographic hypothesis" and creating a source function $S$, which represents the probability to have accumulated transportable sediments at the land's surface with bare soil. African dust sources estimated this way are consistent with studies that used satellite products to locate major dust sources such as TOMS (Total Ozone Mapping Spectrometer) absorbing aerosol index (Prospero et al.,
2002) or MODIS (Moderate Resolution Imaging Spectroradiometer) Deep Blue aerosol products (Ginoux et al., 2010, 2012). The values of the source function $S$ are represented in $0.25^{\circ} \times 0.25^{\circ}$ grid cells in Fig. 9. This figure was used as a reference to validate the source areas of African dust identified by the RCF maps. The three zones of study are also indicated in Fig. 9.

Three main geographical areas were identified in the RCF maps as the greatest potential sources of mineral dust. They agreed fairly well with maxima in the dust source function map (Fig. 9). Table 4 summarizes the main results of this section.

The first source area corresponded with the series of sources starting near the west coast of North Africa at $23^{\circ} \mathrm{N}$, $16^{\circ} \mathrm{W}$ and extending to the north and northeast to $26-27^{\circ} \mathrm{N}$, $6-7^{\circ} \mathrm{W}$ over Western Sahara and northern Mauritania. This potential source area included hydrologic sources such as lakes in the Tiris Zemmour region in northern Mauritania (Ginoux et al., 2012). Source areas are attributed to a hydrological origin based on the presence of ephemeral water bodies such as streams, rivers, lakes, and playas which contain deposits of clay, silt, and salts (Prospero et al., 2002). The second source area corresponded with different regions of Algeria. Large basins (> $200000 \mathrm{~km}^{2}$ ) with sand seas (Grand Erg Oriental and Grand Erg Occidental) are located across central and southern Algeria (Ginoux et al., 2012). The intense dust emission area centered at $26^{\circ} \mathrm{N}, 0^{\circ} \mathrm{E}$ and extending from $22^{\circ} \mathrm{S}$ to $30^{\circ} \mathrm{N}$ (Fig. 9) is considered as the main source area of mineral dust in this area (Prospero et al., 2002). Source areas of dust in Northern Algeria group ephemeral lakes such as Chott el Hodma and Chott ech Chergui (Ginoux et al., 2012). The third source area was located between Tunisia and northeastern Algeria, in an area centered at $34^{\circ} \mathrm{N}, 8^{\circ} \mathrm{E}$. This area also includes ephemeral lakes such as the Chott Jerid in Tunisia and the Chott Melrhir in northeastern Algeria and the sand seas in the Grand Erg Oriental (Prospero et al., 2002; Ginoux et al., 2012) and consequently was distinguished as an intense source area of dust in Fig. 9. All these areas are essentially natural sources (dust emitted from land surfaces where land use is less than $30 \%$; Ginoux et al., 2012). They are active during all the months of the year, but the maximum activity is currently reached from April to September (Prospero et al., 2002). 

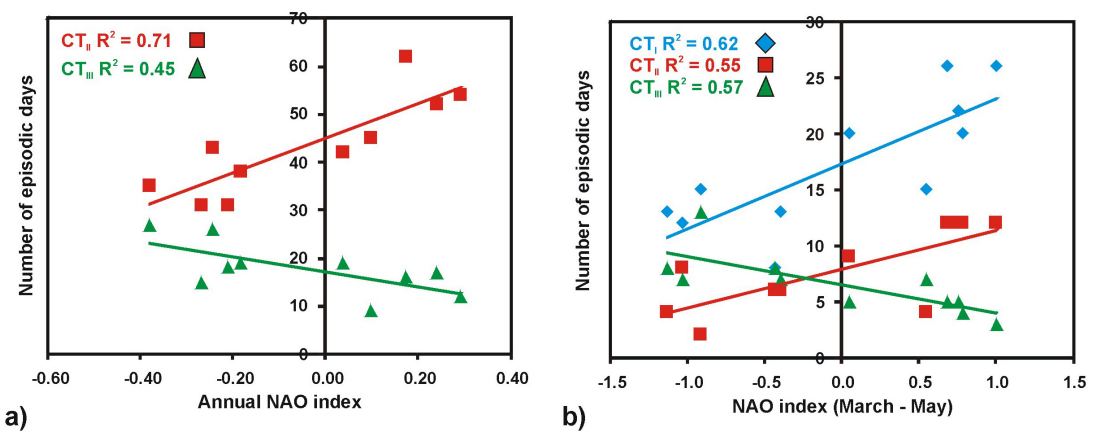

Figure 7. Correlation plot between the annual NAO index (a) and the spring (March-May) NAO index (b), and the number of episodic days for specific circulation types from 2001 to 2011.
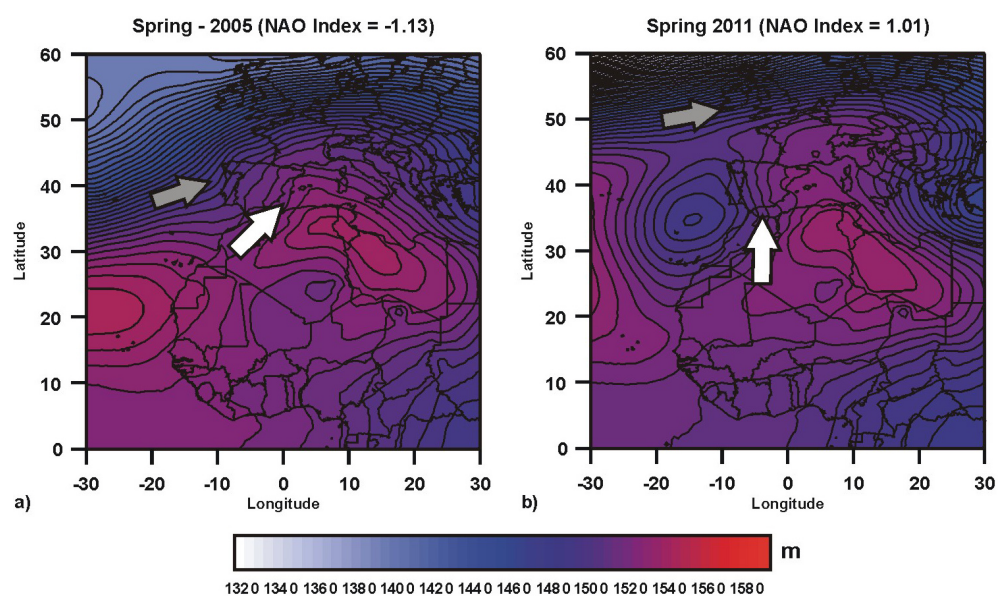

13201340136013801400142014401460148015001520154015601580

$850 \mathrm{hPa}$ Geopotential Height

Figure 8. Composite $850 \mathrm{hPa}$ geopotential height (m) during episodic days in spring 2005 (a) and 2011 (b). Grey and white arrows indicate Atlantic and African air mass flows, respectively.

In relation to the chemical composition of the African dust, it is well known that Tunisia and most of the western $\mathrm{Sa}$ hara lie upon a carbonated lithology. In the occidental Sahara, the coastal basin is composed of Mesozoic and Cenozoic carbonatic sediments, dolomites and marls. By contrast, Precambrian and Paleozoic massifs with low carbonate content cover more southern parts comprising central and southern Algeria, Chad, Sudan, Mali and Mauritania (Chiapello et al., 1997; Moreno et al., 2006). Consequently, higher contents of calcite-dolomite-derived elements should contribute to the mineral dust loading from sources I and III (Fig. 9). Otherwise, dust from source II (Fig. 9) should have a higher content of clay-silicates-derived elements.

The circulation type I transported dust from different source areas. On the one hand the low pressure system located southwest of the Iberian Peninsula coast lead to the transport of dust from Western Sahara and southern Morocco (source I in Fig. 9) towards the western and the central sides of the Iberian Peninsula (Fig. 10a, b). On the other hand, the upper-level high over northern Algeria promoted the transport of dust from northeastern Algeria and Tunisia (Source
III in Fig. 9) towards the eastern side of the Iberian Peninsula and the Balearic Islands (Fig. 10c, d). This type of transport was predominantly produced in summer and autumn.

The circulation type II transported dust mainly from northern Algeria (source II in Fig. 9) in spring and summer, towards each of the three zones of study (Fig. 11a-c).

The longitudinal baric gradient which characterized the circulation type III (Fig. 4) promoted an effective transport of dust in spring, from Western Sahara and southern Morocco (source I in Fig. 9) towards the eastern side of the Iberian Peninsula and the Balearic Islands (Fig. 12a). During winter, the transport of lower concentrations of African dust from regions of northern Morocco was also detected and associated to the circulation type III (Fig. 12b).

The circulation type IV generated the transport of dust essentially from Algeria (source II in Fig. 9). In summer (Fig. 13a, b) the main source areas of dust were located over northern Algeria. Finally in autumn, the North African high was displaced on the way to lower latitudes. Consequently the main sources of dust were identified over more southern regions of Algeria (source II in Fig. 9). The transport of 
Table 4. Greatest potential source areas of African dust obtained for the western, central and eastern regions of the study area, for each circulation type $\left(\mathrm{CT}_{i}\right)$ and season (S1: Western Saharan and Morocco; S2: Algeria; S3: northeastern Algeria and Tunisia).

\begin{tabular}{|c|c|c|c|c|}
\hline & Winter & Spring & Summer & Autumn \\
\hline $\begin{array}{l}\text { Western Iberian } \\
\text { Peninsula }\end{array}$ & ND & $\mathrm{S} 2-\mathrm{CT}_{\mathrm{II}}$ & $\begin{array}{l}\mathrm{S} 1-\mathrm{CT}_{\mathrm{I}} \\
\mathrm{S} 2-\mathrm{CT}_{\mathrm{IV}}\end{array}$ & $\mathrm{S} 1-\mathrm{CT}_{\mathrm{I}}$ \\
\hline $\begin{array}{l}\text { Central Iberian } \\
\text { Peninsula }\end{array}$ & ND & $\mathrm{S} 3-\mathrm{CT}_{\mathrm{IV}}$ & $\begin{array}{l}\text { S1-CT } \\
\text { S2- CT } \\
\text { S2- CT IV }\end{array}$ & $\mathrm{S} 2-\mathrm{CT}_{\mathrm{IV}}$ \\
\hline $\begin{array}{l}\text { Eastern Iberian } \\
\text { Peninsula and the } \\
\text { Balearic Islands }\end{array}$ & $\mathrm{S} 1-\mathrm{CT}_{\mathrm{III}}$ & S1-CT & $\begin{array}{l}\text { S2-CT } \mathrm{CII}_{\mathrm{II}} \\
\mathrm{S}-\mathrm{CT}_{\mathrm{IV}} \\
\mathrm{S}-\mathrm{CT}_{\mathrm{I}}\end{array}$ & $\mathrm{S} 2-\mathrm{CT}_{\mathrm{IV}}$ \\
\hline
\end{tabular}

ND: not determined due to the insufficient number of cases to obtain reliable RCF.

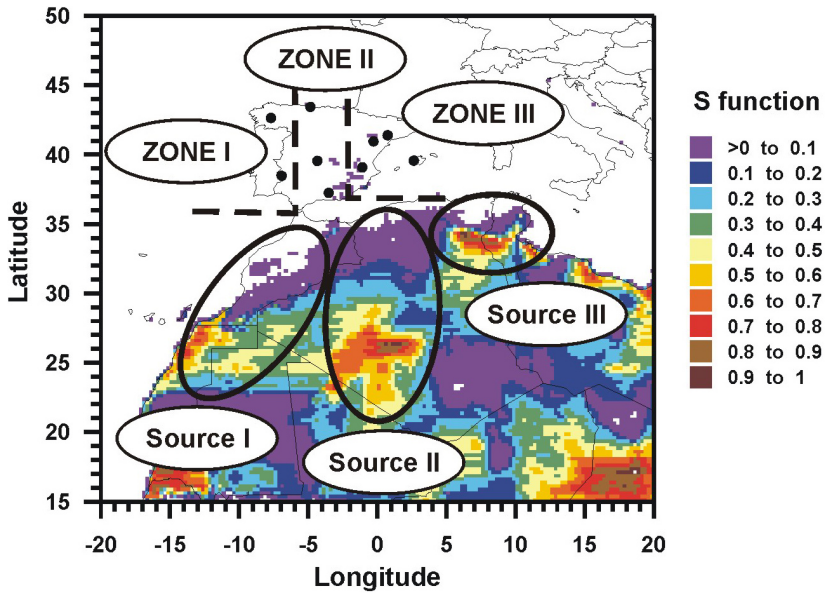

Figure 9. Zones of study and source areas represented over the geographic distribution of the dust source function $S$ (Ginoux et al., 2001). Data obtained from the Atmospheric Physics, Chemistry and Climate Data of the GFDL-NOAA (http://www.gfdl.noaa.gov/ atmospheric-physics-and-chemistry_data). Zone I: western side of the Iberian Peninsula; zone II: central side of the Iberian Peninsula; zone III: eastern side of the Iberian Peninsula and the Balearic Islands. Source I: Western Saharan and Morocco; source II: Algeria; source III: northeastern Algeria and Tunisia.

dust from these source areas was preferably achieved towards the central and eastern sides of the Iberian Peninsula and the Balearic Islands (Fig. 13c, d).

\subsection{Estimation of the impact of ADO produced by the circulation types over different regions of the western Mediterranean Basin}

Table 5 shows the ranges of variation of the impact index values for all the circulation types and the sampling locations. This index accounted for the intensity of the ADO for each circulation type over a specific geographic area, in terms of the average African dust contributions determined at this area and the frequency of occurrence of episodic days.
Table 5. Impact index calculated for each sampling site during each CT leading to ADO over the western Mediterranean Basin in the period 2001-2011.

\begin{tabular}{lrrrr}
\hline & $\mathrm{CT}_{\mathrm{I}}$ & $\mathrm{CT}_{\mathrm{II}}$ & $\mathrm{CT}_{\mathrm{III}}$ & $\mathrm{CT}_{\mathrm{IV}}$ \\
\hline O Saviñao & $38 \%$ & $24 \%$ & $3 \%$ & $35 \%$ \\
Barcarrota & $37 \%$ & $23 \%$ & $7 \%$ & $33 \%$ \\
Viznar & $26 \%$ & $24 \%$ & $11 \%$ & $39 \%$ \\
Niembro & $31 \%$ & $25 \%$ & $10 \%$ & $34 \%$ \\
Risco Llano & $27 \%$ & $20 \%$ & $10 \%$ & $43 \%$ \\
Zarra & $23 \%$ & $22 \%$ & $17 \%$ & $39 \%$ \\
Els Torms & $20 \%$ & $24 \%$ & $18 \%$ & $38 \%$ \\
Monagrega & $20 \%$ & $22 \%$ & $18 \%$ & $40 \%$ \\
Bellver & $17 \%$ & $31 \%$ & $20 \%$ & $33 \%$ \\
\hline
\end{tabular}

Thus, the circulation type I had the largest impact index values in the most western located stations, Barcarrota and O Saviñao, whereas for the other stations the highest impact index values corresponded to the circulation type IV. These circulation types were more frequently registered in summer, when the maximum activity of most of the African sources of dust is currently reached (Prospero et al., 2002). Figure 14 depicts interpolation maps of the impact index values for each circulation type.

Figure $14 \mathrm{a}$ indicates that the ADO produced by the type I circulation had a higher impact at western than at eastern regions. It should be noted that it was demonstrated that this circulation type may induce the transport of African dust towards the western, central and eastern sides of the Iberian Peninsula and the Balearic Islands (Fig. 10). However, owing to the fact that the frequency of episodic days produced by the circulation type I was lower at eastern (15 episodic days per year on average at Zarra) than at western (23 episodic days per year on average at Barcarrota) areas, the resulting impact index was higher at the western areas.

In comparison with the circulation type I, the circulation type II produced a higher frequency of episodic days but also lower average values of the African dust contributions 


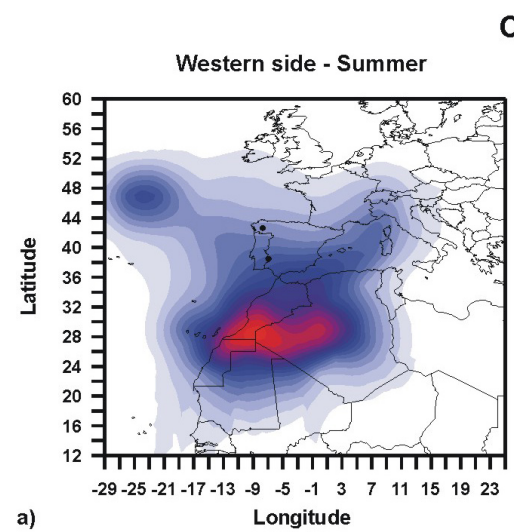

Circulation Type I

a)

Dust $\left(\mu \mathrm{g} / \mathrm{m}^{3}\right)$

Central side - Summer

Dust $\left(\mu \mathrm{g} / \mathrm{m}^{3}\right)$
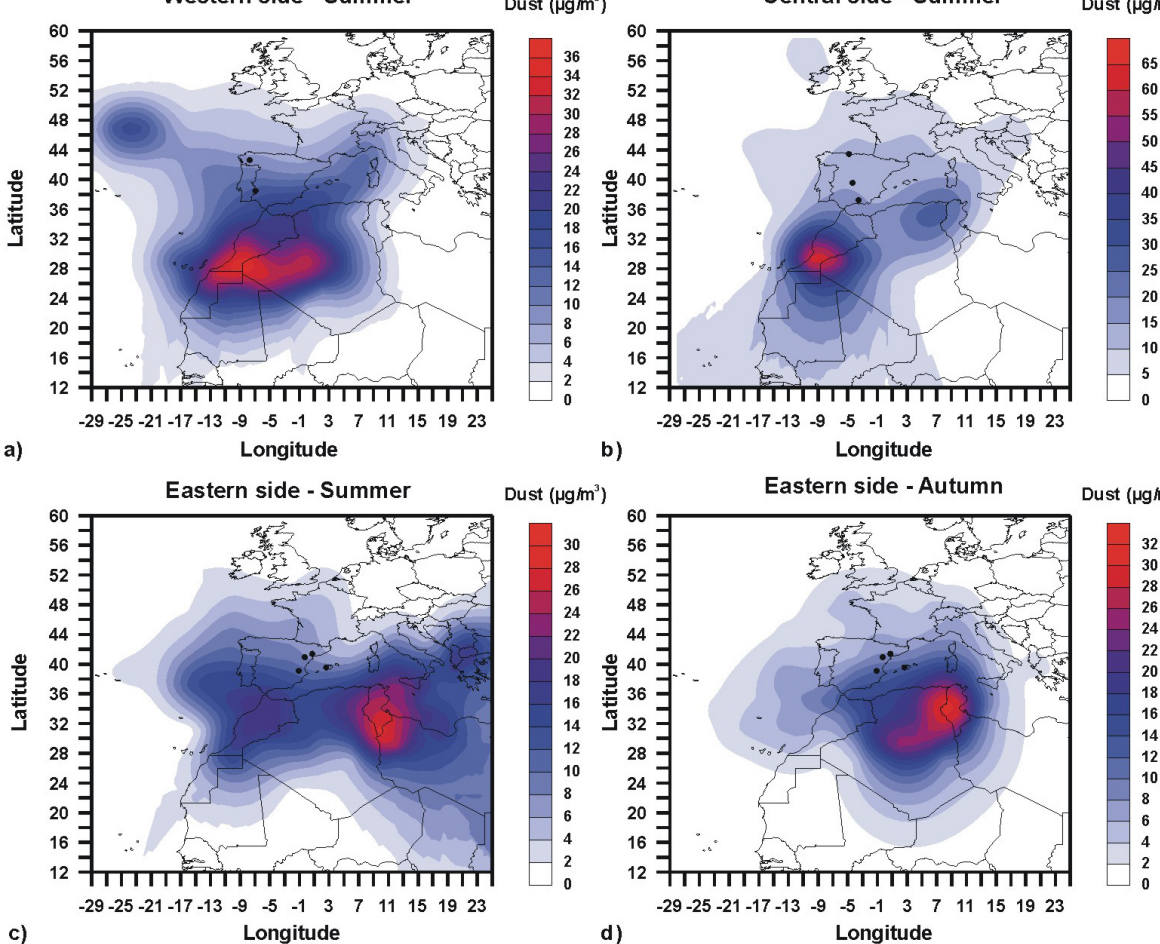

Dust $\left(\mu \mathrm{g} / \mathrm{m}^{3}\right)$

Eastern side - Autumn

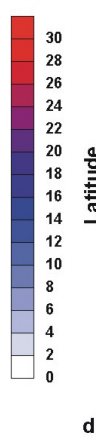

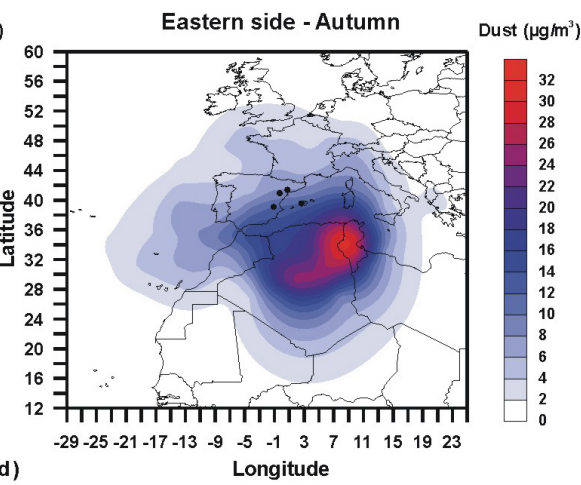

Figure 10. RCFs for African dust contributions $\left(\mu \mathrm{g} \mathrm{m}^{-3}\right)$ during ADO generated by circulation type I over the western, central and eastern sides of the area of study in summer and autumn.
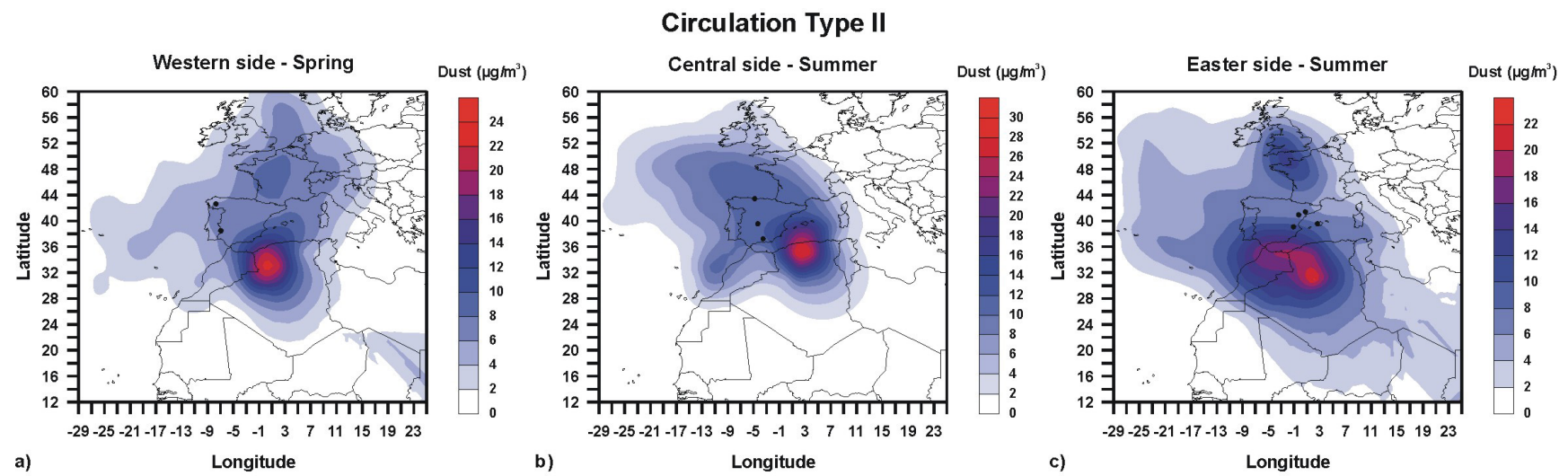

Figure 11. RCFs for African dust contributions $\left(\mu \mathrm{g} \mathrm{m}^{-3}\right)$ during ADO generated by circulation type II over the western, central and eastern sides of the area of study in spring and summer.

at most of the sampling sites. As a consequence, the impact index was lower for all the sites except for those located at the most eastern locations (Els Torms, Monagrega and Bellver; Table 5). This circulation type generated a similar impact index across all the Iberian Peninsula (from $20 \%$ at Risco Llano to $24 \%$ at Els Torms and O Saviñao). The highest impact index was obtained at the Balearic Islands site $(31 \%$ at Bellver, Fig. 14b) as a consequence of the typical south- westerly wind flows, generated by these synoptic meteorological situations (Fig. 3).

The prevalent southwestern circulation over the western Mediterranean Basin associated to the circulation pattern III (Fig. 4) generated higher values of the impact index at eastern than at western locations of the study area (Fig. 14c). The impact index was lower than $10 \%$ at the western sites, rising to $17-18 \%$ at the eastern sites (Zarra, Els Torms and Monagrega) and to $20 \%$ at the Balearic Islands site (Bellver). 


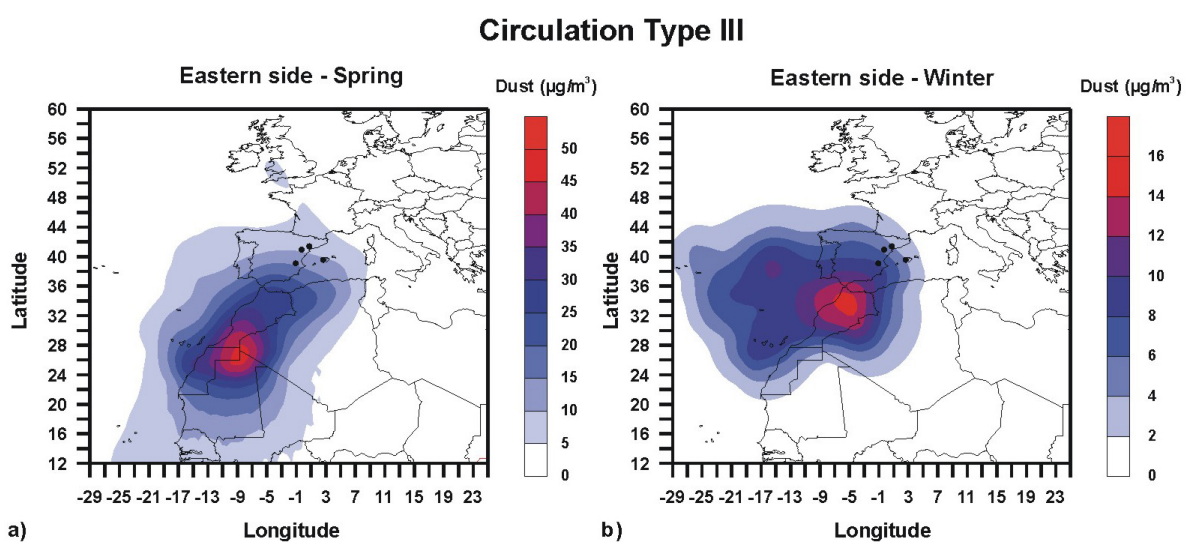

Figure 12. RCFs for African dust contributions $\left(\mu \mathrm{g} \mathrm{m}^{-3}\right)$ during ADO generated by circulation type III over the eastern side of the area of study in spring and winter.
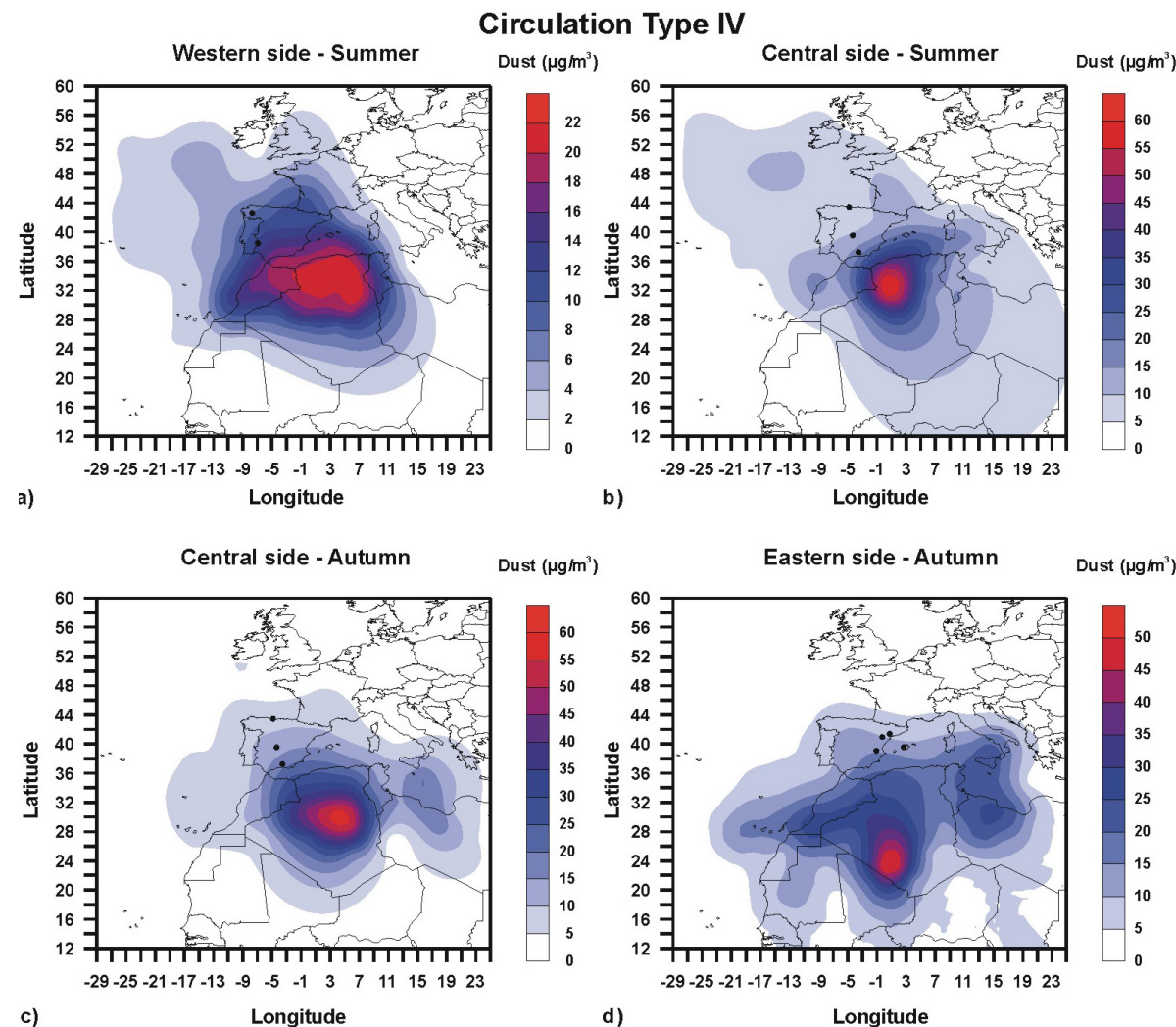

Figure 13. RCFs for African dust contributions $\left(\mu \mathrm{g} \mathrm{m}^{-3}\right)$ during ADO generated by circulation type IV over the western, central and eastern sides of the area of study in summer and autumn.

Because of the low frequency of occurrence of this circulation type (Table 3 ) the impact index values were the lowest obtained for all the sampling sites, with the exception of Bellver (Table 5).

Finally, the circulation type IV generated higher impact index values at southern, eastern and central areas than at western and northern regions of the Iberian Peninsula and the Balearic Islands (Fig. 14d). In these cases, the air masses coming from North Africa were heavily loaded with dust and the frequency of episodic days was very high, especially in summer and autumn (Table 3). Consequently the impact index was the highest obtained for most of the sites. 

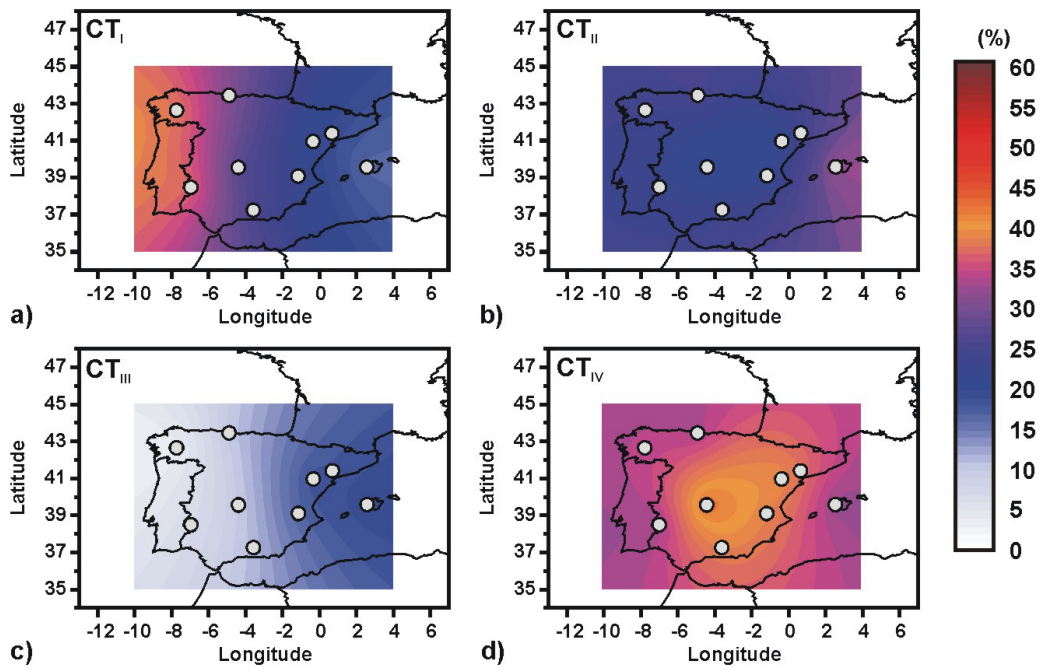

Figure 14. Interpolation maps of the impact index (\%) estimated at the regional background stations, during circulation types leading to ADO over the western Mediterranean Basin in the period 2001-2011.

\section{Conclusions}

In this work the occurrence of ADO over the western Mediterranean Basin were analyzed over an 11-year period (2001-2011) with the aim to characterize the prevailing atmospheric circulation patterns and the associated dust source areas. Estimations of the values of African dust contribution in $\mathrm{PM}_{10}$ during each event were obtained at nine regional background sites across the western Mediterranean Basin and analyzed together with daily fields of meteorological variables and daily air mass back trajectories arriving at these sites. The impact of the ADO produced by each circulation type was estimated in terms of the average contribution of the African dust on the ambient levels of $\mathrm{PM}_{10}$ concentrations and the frequency of episodic days.

The summer months dominated ADO occurrence ( $40 \%$ of the total number of episodic days produced during the 20012011 period) under two prevailing circulation types (circulation types I and IV). Their transport mechanisms were composed of two stages. In the first stage, convective injection of dust from source areas was produced by the intense surface heating. In the second stage, transport towards the Iberian Peninsula and the Balearic Islands was produced at the upper levels, being driven by the North African high, alone in the case of the circulation type IV or in combination with a relative low pressure system placed west of the Iberian Peninsula coast in the case of the circulation type I. ADO produced during the circulation type IV generated the highest impact at southern, eastern and central areas of the Iberian Peninsula and the Balearic Islands. The transport of dust was predominantly produced from northern and southern areas of Algeria in summer and autumn, respectively.

Events generated by the circulation type I produced a higher impact at western than at eastern areas of the Iberian
Peninsula. The transport of dust was produced from Western Sahara and southern Morocco towards the western and the central sides of the Iberian Peninsula and from northeastern Algeria and Tunisia towards the eastern side of the Iberian Peninsula and the Balearic Islands.

The circulation types II and III were more frequently produced during the spring season. They were characterized by a displacement of the North African high to the east and by a stronger baric gradient than the one obtained in the circulation types I and IV. South to southwestern winds were the prevailing flows generated by these synoptic situations, transporting dust mainly from northern Algeria in the case of the circulation type II and from Western Sahara and Morocco in the case of the circulation type III. Our results indicated a progressive higher influence of the ADO originated during these circulation types towards the eastern areas of the Iberian Peninsula and the Balearic Islands.

The occurrence of the different circulation types was associated with the values of the NAO index. In fact, this index was observed to influence the frequency of episodic days across the western Mediterranean Basin during spring. In this period higher (lower) than normal values of the NAO index were associated with higher (lower) frequency of circulation types I and II. This suggests that when NAO was more intensely positive, the probability of transporting air masses from North Africa towards the Iberian Peninsula was higher. On the contrary during negative NAO phases in spring, the advection of Atlantic air masses was produced at lower latitudes than usual, thus preventing subtropical air masses from reaching this area. However, during specific events characterized by the presence of high pressure systems located over eastern Algeria, Tunisia and Libya, as those described by circulation type III, the transport of the African air masses towards the eastern side of the Iberian Peninsula and the 
Balearic Islands and the central Mediterranean could be produced.

The results obtained in this study demonstrate that the ADO across the western Mediterranean Basin were caused by different atmospheric circulation patterns, which condition their intensity and the areas affected by mineral dust. The four main synoptic meteorological situations that generate this type of events were described in this work and the highest potential source areas of mineral dust, associated to each of them, were also characterized. This information can be used as a complementary tool for forecasts and analyses of aerosol properties as well as their effects on human health, ecosystems or rain composition, distinguishing between air masses coming from different areas of the African continent.

\section{The Supplement related to this article is available online at doi:10.5194/acp-14-6759-2014-supplement.}

Acknowledgements. This work was funded by the Spanish Ministry of the Environment and Rural and Marine Affairs under the project "Estudio y evaluacion de la contaminacion atmosferica por material particulado y metales en España" (UCA 2009020083) and by research projects GRACCIE-CSD2007-00067, MICROSOL (CGL2011-27020) and VAMOS (CGL2010-19464/CLI). The authors wish to thank the EMEP programme, supplying $\mathrm{PM}_{10}$ data used in this study and the NOAA Air Resources Laboratory (ARL) for the provision of the HYSPLIT trajectory model. We acknowledge the Atmospheric Modelling \& Weather Forecasting Group in the University of Athens, the Earth Science Dpt. from the Barcelona Supercomputing Centre, the Naval Research Laboratory and the SeaWiFS project (NASA) for the provision of the SKIRON, DREAM/BSC-DREAM8b, NAAPs aerosol maps, and the satellite imagery, respectively.

Edited by: E. Gerasopoulos

\section{References}

Alonso-Pérez, S., Cuevas, E. and Querol, X.: Objective identification of synoptic meteorological patterns favouring African dust intrusions into the marine boundary layer of the subtropical Eastern north Atlantic región, Meteorol. Atmos. Phys., 113, 109-124, 2011.

Artíñano, B., Querol, X., Salvador, P., Rodríguez, S., Alonso, D. G., and Alastuey, A.: Assessment of airborne particulate levels in Spain in relation to the new EU-Directive, Atmos. Environ., 35, S43-S53, 2001.

Bouchlaghem, K., Nsom, B., Latrache, N., and Haj Kacem, H.: Impact of Saharan dust on $\mathrm{PM}_{10}$ concentration in the Mediterranean Tunisian coasts, Atmos. Res., 92, 531-539, 2009.

Carslaw, D. C. and Ropkins, K.: Openair - an R package for air quality data analysis, Environ. Modell. Softw., 27-28, 52-61, 2012.

Carslaw, D. C., Beevers, S. D., and Tate, J. E.: Modelling and assessing trends in traffic-related emissions using a generalised additive modelling approach, Atmos. Environ., 41, 5289-5299, 2007.

Chiapello, I., Bergametti, G., Chatenet, B., Bousquet, P., Dulac, F., and Santos Soares, E.: Origins of African dust transported over the North-Eastern Tropical Atlantic, J. Geophys. Res., 102, 13701-13709, 1997.

Commission staff working paper, establishing guidelines for demonstration and subtraction of exceedances attributable to natural sources under the Directive 2008/50/EC on ambient air quality and cleaner air for Europe, Brussels, 15.02.2011. SEC(2011) 208 final, 37 pp., available at: http://ec.europa.eu/environment/ air/quality/legislation/pdf/sec_2011_0208.pdf, (last access: January 2014), 2011.

Cusack, M., Alastuey, A., Pérez, N., Pey, J., and Querol, X.: Trends of particulate matter $\left(\mathrm{PM}_{2.5}\right)$ and chemical composition at a regional background site in the Western Mediterranean over the last nine years (2002-2010), Atmos. Chem. Phys., 12, 8341-8357, doi:10.5194/acp-12-8341-2012, 2012.

Dee, D. P., Uppala, S. M., Simmons, A. J., Berrisford, P., Poli, P., Kobayashi, S., Andrae, U., Balmaseda, M. A., Balsamo, G., Bauer, P., Bechtold, P., Beljaars, A. C. M., van de Berg, L., Bidlot, J., Bormann, N., Delsol, C., Dragani, R., Fuentes, M., Geer, A. J., Haimberger, L., Healy, S. B., Hersbach, H., Hölm, E. V., Isaksen, L., Kallberg, P., Köhler, M., Matricardi, M., McNally, A. P., Monge-Sanz, B. M., Morcrette, J.-J., Park, B.-K., Peubey, C., de Rosnay, P., Tavolato, C., Thépaut, J.-N., and Vitart, F.: The ERA-Interim reanalysis: configuration and performance of the data assimilation system, Q. J. Roy. Meteor. Soc., 137, 553-597, 2011.

Dorling, S. R., Davies, T. D., and Pierce, C. E.: Cluster analysis: a technique for estimating the synoptic meteorological controls on air and precipitation chemistry - method and applications, Atmos. Environ., 26A, 2575-2581, 1992.

Draxler, R. R. and Rolph, G. D.: HYSPLIT (HYbrid Single-Particle Lagrangian Integrated Trajectory), online, Silver Spring. MD. Model access via NOAA ARL READY Website: http://www.arl. noaa.gov/ready/hysplit4.html, (last access: July 2014), 2003.

Escudero, M., Castillo, S., Querol, X., Avila, A., Alarcón, M., Viana, M. M., Alastuey, A., Cuevas, E., and Rodríguez, S.: Wet and dry African dust episodes over eastern Spain, J. Geophys. Res. 110, D18S08, doi:10.1029/2004JD004731, 2005.

Escudero, M., Querol, X., Ávila A., and Cuevas, E.: Origin of the exceedances of the European daily PM limit value in regional background áreas of Spain, Atmos. Environ., 41, 730-744, 2007a.

Escudero, M., Querol, X., Pey, J., Alastuey, A., Pérez, N., Ferreira, F., Alonso, S., Rodríguez, S., and Cuevas, E.: A methodology for the quantification of the net African dust load in air quality monitoring networks, Atmos. Environ., 41, 5516-5524, $2007 \mathrm{~b}$.

Gerasopoulos, E., Kouvarakis, G., Babasakalis, P., Vrekoussis, M., Putaud, J. P., and Mihalopoulos, N.: Origin and variability of particulate matter $\left(\mathrm{PM}_{10}\right)$ mass concentrations over the Eastern Mediterranean, Atmos. Environ., 40, 4679-4690, 2006.

Ginoux, P., Chin, M., Tegen, I., Prospero, J., Holben, B., Dubovik, O., and Lin, S. J.: Sources and distributions of dust aerosols simulated with the GOCART model, J. Geophys. Res., 106, 2025520273, doi:10.1029/2000JD000053, 2001.

Ginoux, P., Garbuzov, D., and Hsu, H. C.: Identification of anthropogenic and natural dust sources using Moderate Resolution 
Imaging Spectroradiometer (MODIS) Deep Blue level 2 data, J. Geophys. Res., 115, D05204, doi:10.1029/2009JD012398, 2010.

Ginoux, P., Prospero, J. M., Gill, T. E., Hsu, H. C., and Zhao, M.: Global-scale attribution of anthropogenic and natural dust sources and their emission rates based on MODIS Deep Blue aerosol products, Rev. Geophys., 50, RG3005, doi:10.1029/2012RG000388, 2012.

Gong, X. and Richman, M. B.: On the application of cluster analysis to growing season precipitation data in North America east of the Rockies, J. Climate, 8, 897-931, 1995.

Hirsch, R., Slack, J. R., and Smith, R. A.: Techniques of trend analysis for monthly water quality data, Water Resour. Res., 18, 107$121,1982$.

Hurrell J. W.: Decadal trend in the North Atlantic Oscillation: Regional temperatures and precipitations, Science, 269, 676-679, 1995.

Huth, R.: An intercomparison of computer-assisted circulation classification methods, Int. J. Climatol., 16, 893-922, 1996.

Huth, R., Beck, C., Philipp, A., Demuzere, M., Ustrnul, Z., Cahynová, M., Kyselý, J., and Tveito, O. E.: Classifications of atmospheric circulation patterns: recent advances and applications, Ann. NY Acad. Sci., 1146, 105-152, 2008.

Kidson, J. W.: The utility of surface and upper air data in synoptic climatological specification of surface climatic variables, Int. J. Climatol., 17, 399-413, 1997.

Lupu, A. and Maenhaut, W.: Application and comparison of two statistical trajectory techniques for identification of source regions of atmospheric aerosol species, Atmos. Environ., 36, 5607-5618, 2002.

Michelangeli, P. A., Vautard, R., and Legras, B.: Weather regimes: Recurrence and quasi stationary, J. Atmos. Sci., 52, 1237-1256, 1995.

Moreno, T., Querol, X., Castillo, S., Alastuey, A., Cuevas, E., Herrmann, L., Mounkaila, M., Elvira, J., and Gibbons, W.: Geochemical variations in aeolian mineral particles from the SaharaSahel Dust Corridor, Chemosphere, 65, 261-270, 2006.

Moulin, C., Lambert, C. E., Dayan, U., Masson, V., Ramonet, M., Bousquet, P., Legrand, M., Balkanski, Y. J., Guelle, W., Marticorena, B., Bergametti, G., and Dulac, F.: Satellite climatology of African dust transport in the Mediterranean atmosphere, J. Geophys. Res., 103, 13137-13144, 1998.

Moulin, D., Lambert, C. E., Dulac, F., and Dayan, U.: Control of atmospheric export of dust from North Africa by the North Atlantic Oscillation, Nature, 387, 691-694, 1997.

Palmero, D., Rodríguez, J. M., de Cara, M., Camacho, F., Iglesias, C., and Tello, J. C.: Fungal microbiota from rain water and pathogenicity of Fusarium species isolated from atmospheric dust and rainfall dust, J. Ind. Microbiol. Biot., 38, 13-20, doi:10.1007/s10295-010-0831-5, 2011.

Pérez, L., Tobías, A., Querol, X., Kunzli, N., Pey, J., Alastuey, A., Viana, M., Valero, N., González-Cabré, M., and Sunyer, J.: Coarse Particles from Saharan Dust and Daily Mortality, Epidemiology, 19, 800-807, 2008.

Pey, J., Querol, X., Alastuey, A., Forastiere, F., and Stafoggia, M.: African dust outbreaks over the Mediterranean Basin during 2001-2011: $\mathrm{PM}_{10}$ concentrations, phenomenology and trends, and its relation with synoptic and mesoscale meteorology, Atmos. Chem. Phys., 13, 1395-1410, doi:10.5194/acp-13-13952013, 2013.
Philipp, A., Della-Marta, P. M., Jacobeit, J., Fereday, D. R., Jones, P. D., Moberg, A., and Wanner, H.: Long-term variability of daily North-Atlantic-European pressure patterns since 1850 classified by simulated annealing clustering, J. Climate, 20, 4065-4095, 2007.

Prospero, J. M.: Long-term measurements of the transport of African mineral dust to the southeastern United States: Implications for regional air quality, J. Geophys. Res., 104, 1591715927, 1999.

Prospero, J. M. and Lamb, P. J.: African droughts and dust transport to the Caribbean: Climate change implications, Science, 7, 1024 1027, doi:10.1126/science.1089915, 2003.

Prospero, J. M., Glaccum, R. A., and Nees, R. T.: Atmospheric transport of soil dust from Africa to South America, Nature, 289, 570-572, 1981.

Prospero, J. M., Ginoux, P., Torres, O., Nicholson, S. E., and Gill, T. E.: Environmental characterization of global sources of atmospheric soil dust identified with the Nimbus 7 Total Ozone Mapping Spectrometer (TOMS) absorbing aerosol product, Rev. Geophys., 40, 1002, doi:10.1029/2000RG000095, 2002.

Querol, X., Alastuey, A., Puicercus, J. A., Mantilla, E., Miró, J. V., López-Soler, A., Plana, F., and Artíñano, B.: Seasonal evolution of suspended particles around a large coal-fired power station: particles levels and sources, Atmos. Environ., 32, 1963-1978, 1998.

Querol, X., Alastuey, A., Rodriguez, S., Viana, M., Artíñano, B., Salvador, P., Mantilla, E., Garcia, S., Fernandez, R., de la Rosa, J., Sanchez, A., Menendez, M., and Gil, J.: Levels of particulate matter in rural, urban and industrial sites in Spain, Sci. Total Environ., 334-335, 359-376, 2004.

Querol, X., Alastuey, A., Moreno, T., Viana, M. M., Castillo, S., Pey, J., Rodriguez, S., Artíñano, B., Salvador, P., Sánchez, M., Garcia, S., Herce, M. D., Fernandez, R., Moreno, S., Negral, L., Minguillón, M., Monfort, E., Sanz, M., Palomo, R., Pinilla, E., Cuevas, E., de la Rosa, J., and Sanchez A., Spatial and temporal variations in airborne particulate matter $\left(\mathrm{PM}_{10}\right.$ and $\left.\mathrm{PM}_{2.5}\right)$ across Spain 1999-2005, Atmos. Environ., 42, 3964-3979, 2008.

Querol, X., Pey, J., Pandolfi, M., Alastuey, A., Cusack, M., Pérez, N., Moreno, N., Viana, M., Mihalopoulos, N., Kallos, G., and Kleanthous, S.: African dust contributions to mean ambient $\mathrm{PM}_{10}$ mass-levels across the Mediterranean basin, Atmos. Environ., 43, 4266-4277, 2009.

Reyes, M., Diaz, J., Tobías, A., Montero, J. C., and Linares, C.: Impact of Saharan dust particles on hospital admissions in Madrid (Spain), Int. J. Environ. Heal. R., 24, 63-72, doi:10.1080/09603123.2013.782604, 2014.

Rodríguez, S., Querol, X., Alastuey, A., Kallos, G., and Kakaliagou, O.: Saharan dust contributions to $\mathrm{PM}_{10}$ and TSP levels in Southern and Eastern Spain, Atmos. Environ., 35, 2433-2447, 2001.

Rodríguez, S., Alastuey, A., Alonso-Pérez, S., Querol, X., Cuevas, E., Abreu-Afonso, J., Viana, M., Pérez, N., Pandolfi, M., and de la Rosa, J.: Transport of desert dust mixed with North African industrial pollutants in the subtropical Saharan Air Layer, Atmos. Chem. Phys., 11, 6663-6685, doi:10.5194/acp-11-66632011, 2011.

Romero, R., Sumner, G., Ramis, C., and Genovs, A.: A classification of the atmospheric circulation patterns producing significant daily rainfall in the Spanish Mediterranean area, Int. J. Climatol., 19, 765-785, 1999. 
Salvador, P., Artíñano, B., Alonso, D., Querol, X., and Alastuey, A.: Identification and characterisation of sources of $\mathrm{PM}_{10}$ in Madrid (Spain) by statistical methods, Atmos. Environ., 38, 435-447, 2004.

Salvador, P., Artíñano, B., Querol, X., and Alastuey, A.: A combined analysis of backward trajectories and aerosol chemistry to characterise long-range transport episodes of particulate matter: The Madrid Air Basin, a case study, Sci. Total Environ., 390, 495-506, 2008.

Salvador, P., Artíñano, B., Molero, M., Viana, M., Pey, J., Alastuey, A., and Querol, X.: African dust contribution to ambient aerosol levels across central Spain: Characterization of long-range transport episodes of desert dust, Atmos. Res., 127, 117-129, 2013.

Scheifinger, H. and Kaiser, A.: Validation of trajectory statistical methods, Atmos. Environ., 41, 8846-8856, 2007.

Stohl, A.: Trajectory statistics-a new method to establish sourcereceptor relationships of air pollutants and its application to the transport of particulate sulfate in Europe, Atmos. Environ., 30, 579-587, 1996.

Stohl, A.: Computation, accuracy and applications of trajectories a review and bibliography, Atmos. Environ., 32, 947-966, 1998.

Tobías, A., Caylá, J. A., Pey, J., Alastuey, A., and Querol, X.: Are Saharan dust intrusions increasing the risk of meningococcal meningitis?, Int. J. Infect. Dis., 15, e503, doi:10.1016/j.ijid.2011.03.008, 2011a.
Tobías, A., Pérez, L., Díaz, J., Linares, C., Pey, J., Alastuey, A., and Querol, X.: Short-term effects of particulate matter on daily mortality during Saharan dust outbreaks: A case-crossover analysis in Madrid (Spain), Sci. Total Environ., 412-413, 386-389, 2011b.

Viana, M., Querol, X., Alastuey, A., Cuevas, E., and Rodríguez, S.: Influence of African dust on the levels of atmospheric particulates in the Canary Islands air quality network. Atmos. Environ., 36, 5861-5875, 2002.

Viana, M., Querol, X., Alastuey, A., Gangoiti, G., and Menéndez M.: PM levels in the Basque Country (Northern Spain): analysis of a 5-year data record and interpretation of seasonal variations, Atmos. Environ., 37, 2879-2891, 2003.

Viana, M., Salvador, P., Artíñano, B., Querol, X., Alastuey, A., Pey, J., Latz, A. J., Cabañas, M., Moreno, T., García, S., Herce, M., Diez, P., Romero, D., and Fernández, R.: Assessing the performance of methods to detect and quantify African dust in airborne particulates, Environ. Sci. Technol., 44, 8814-8820, 2010.

Vinogradova, A. A.: Anthropogenic pollutants in the Russian Arctic atmosphere: sources and sinks in spring and summer, Atmos. Environ., 34, 5151-5160, 2000.

Yarnal, B.: Synoptic Climatology in Environmental Analysis, Belhaven Press, London, UK, 195 pp., 1993. 